\title{
GENDER EXPERTS AND CRITICAL FRIENDS: RESEARCH IN RELATIONS OF PROXIMITY
}

\author{
AikoHolvikivi,a.i.holvikivi@Ise.ac.uk \\ London School of Economics and Political Science, United Kingdom
}

Research on gender expertise is often conducted from relations of proximity between academics and gender experts, raising familiar feminist methodological questions about the researcher/researched relationship. In this article, I take up the suggestion that such relationships should be guided by the principles of 'critical friendship'. I argue that critical friendship should be understood as a two-way relationship that creates space to negotiate the goals of gender expertise and how it is practiced. I also caution that relations of critical friendship may cause researchers to privilege the perspectives of Global North gender experts in academic analyses, while silencing other voices.

Key words gender expertise; feminist research methods; fieldwork; critical friendship; research ethics; militarisation

\section{Key messages}

- Research on gender experts is often conducted from relations of proximity.

- Research relationships between feminist academics and gender experts can be understood as 'critical friendship'.

- Critical friendship must allow for feminist ambiguity about the politics of gender expertise.

- Critical friendship may problematically privilege the voices of gender experts located in the Global North.

\section{INTRODUCTION}

Research on gender expertise by feminist academics often involves the production of knowledge from relations of personal and professional proximity (Bustelo et al., 2016b, Eyben, 2010, Prügl and Thompson, 2017). This proximity raises familiar feminist methodological questions about the researcher/researched relationship and its impact on knowledge production. The concept of "critical friendship" has been proposed as a useful tool to navigate the political and ethical tensions such relations of proximity introduce to research methodology (Chappell and Mackay, 2015, Bastick and Duncanson, 2015). In this article, I provide examples from research conducted with gender experts to 
examine how critical friendship plays out in the research endeavour. I develop the concept further by arguing that critical friendship is not a unidirectional relationship, and that feminist researchers should also create space for gender experts to be critical friends to researchers. Further, I draw attention to what critical friendship excludes, highlighting the ways in which such relationships facilitate the representational privileging of actors based in the Global North. Overall, I suggest that attention to the concept of critical friendship underscores the continued importance of reflecting on the positionality of the researcher, with a view to producing knowledge that is (more) methodologically rigorous, ethically sound, and politically responsible.

This analysis is based on auto-ethnographic reflections on research with gender experts involved in gender training in the peace and security sector. This research was inspired by my professional experience and facilitated by personal relationships: between 2011 and 2015 I was employed as a gender 'expert' in the field of peace and security by a Western European international nongovernmental organisation (INGO). As part of this work, I facilitated gender training with security actors including police and military personnel. Facilitating such training was a source of endless questions for me - questions I wished to explore at greater depth, and with the critical freedom academic inquiry would provide. The reflections in this article draw from this inquiry: they derive from a larger, on-going research project devoted to the analysis of gender training for uniformed ${ }^{1}$ peacekeepers, which seeks to interrogate how knowledge about gender is produced and circulated through training as transnational practice. My prior employment as a gender expert means that my research was conducted from the vantage point of a "recovering femocrat", within a community of practice that I had been part of (Chappell and Mackay, 2015). It means that my access to conduct research in security institutions was mediated through personal and professional connections from my time as an insider to the community. It means that I came to the research endeavour already having had the experience of being interviewed and written about as a 'gender expert' whose professional practice was the object of research. Eve Kosofsky Sedgwick's words ring true of this endeavour: "what brings me to this work can hardly be that I am a woman, or a feminist, but that I am this particular one" (2008, emphasis in original). In continuity with the recognition that this is research conducted from a specific personal history, social location, and field of gender expertise, it should be noted that the analysis in this article pertains to a particular research context.

Nonetheless, the evolving body of literature on gender expertise in global governance suggests that my experience is not unique; indeed, it may even constitute a common characteristic of such research. Scholarship on gender expertise often involves researchers writing about their current or former colleagues, institutions they have worked or consulted for, their friends, and sometimes even themselves (Bustelo et al., 2016a). This process of undoing neat distinctions between researcher and researched carries implications both for how gender expertise is practiced, and how knowledge about such practices is produced. Given the ubiquity of such research dynamics, developing the concept of critical friendship contributes to broader methodological concerns of feminist research on gender expertise.

In the following section, I outline the research endeavour that informs these reflections, describe the relationships that characterise it, and identify the factors which contribute to fostering proximity. Next, I situate this research within a review of the feminist methodological literature on researcher/researched relationships, examining in particular the concept of critical friendship. I then turn to examine two distinct ways in which relations of proximity produce political and ethical 
dilemmas. I characterise these tensions as pertaining to the ethics of critical friendship and to the politics of representation. I conclude by reflecting on the implications of these contributions for research on gender experts and gender expertise.

\section{RESEARCH WITH GENDER EXPERTS}

This article draws from a qualitative study of gender training for uniformed peacekeepers, which involved as participants a community of gender experts in the peace and security field. The broader study examines the politics of gender training, interrogating through the lens of feminist pedagogies how knowledge about gender is produced, translated, contested and negotiated through the process of training. The research methods consisted of close readings of key documents (training curricula, etc.), participant observation of training, and interviews with gender trainers and training participants. In this section, I provide an overview of the research that informs the analysis in this paper, and account for the factors that fostered relations of proximity during the research.

My analysis draws primarily from the fieldwork component of the research: participant observation and interviews. Between November 2016 and December 2017, I conducted participant observation in seven training courses on gender for uniformed peacekeepers. This included two one-hour training sessions, three one-week long courses, and two two-week long courses, amounting to a total of eight weeks of observation. Two training courses took place in a national context in a Nordic country, and the others were multinational courses held in the Nordic region, Western Europe, the Western Balkans, East Africa, and West Africa.* Further, between May 2016 and June 2017, I conducted semistructured interviews with additional gender experts outside of this participant observation. I conducted 29 interviews with 23 respondents: 14 women and 9 men; 6 military and 17 civilian. Among the civilian respondents, four were employed by the defence sector (military academies and ministries of defence), four by the United Nations (UN), eight by INGOs (six different organisations) and one by an academic institution. All were employed full time by their respective organisations.

The interviewees were all involved in the design or delivery of gender training for uniformed peacekeepers. They can be considered "gender experts", as their jobs involve a type of performance of expertise on gender (Prügl and Thompson, 2017, Bustelo et al., 2016b). However, in terms of their job description, experience, and level of expertise on gender, the interviewees constituted a heterogeneous group. Some held training or educational positions in military institutions, and occasionally delivered training on gender, often with little prior knowledge of the topic. Others worked as military gender advisors, and training formed one part of their tasks in fulfilment of this role. Similarly, many of the UN and INGO staff interviewed were employed as gender experts, engaging in a variety of gender -related activities such as policy advocacy and research, and were regularly invited to deliver training within military and police institutions. Most - like myself at the time of my INGO employment - had acquired their gender expertise 'on the job'.

While the primary focus of the research was on training, in several of the interviews, the relationship between gender experts and academic researchers was discussed at some length. The topic arose in response to questions about how interviewees developed their expertise on gender. Some interviewees - notably those employed by INGOs - mentioned encountering gender studies during their university studies; participating in knowledge exchange workshops and conferences with academic researchers; and prior experiences of being researched and engaging informally in 
continued conversations with academic researchers. These mentions prompted further discussion about the relationship between the work of gender experts and the work of academic researchers.

What emerges from this description of the research participants is a snapshot of a diverse group of individuals who are all involved in practicing a form of gender expertise through training on the topic. Gender expertise is a contested field, and "gender experts do not constitute a monolithic formation" (Kunz et al., 2017). This diversity hints at differential positionings among this group vis-à-vis the researcher, and hence differing levels of proximity between researcher and researched. Three key factors increased proximity: ongoing relationships; positional slippages; and political solidarity.

First, many of those involved in the research were prior acquaintances. Out of the interview respondents, eleven were individuals whom I knew personally prior to commencing the research project. Similarly, nearly all the courses I observed involved at least one individual who was a prior acquaintance. This on-going and often personal nature of my acquaintance with some of the research participants is significant because it suggests that the description of research as temporally and geographically bounded encounters such as training courses and interviews is only part of the story. These formal moments of research are supplemented by on-going informal exchanges in academic and practitioner workshops, and social encounters over meals, in bars, and through email and social media. In other words, much of the research was conducted within the context of friendships that exceed the formal research encounter.

Second, and related, is the fact that I had personal experience of working within the Global North INGO gender expert community; I was a (former) insider. However, insider/outsider was not a stable duality, rather, the facets of 'insiderness' and 'outsiderness' in this research endeavour were multiple and shifting. Many of the gender experts are also outsiders to the military organisations they work with, by virtue either of institutional location (INGO staff invited in) or by job function (military gender advisers who work against the grain of an organisation of hegemonic masculinity) (Kronsell, 2006). As researcher, I was insider to their world by virtue of having occupied a similar position, but simultaneously outsider, because I was not constrained in my work by their organisational mandates. Because this community is dominated by the Global North, I shared with many of the gender experts facets of 'insiderness' that involve an education in Western universities, and a passable fluency in the cultural and technocratic scripts of the institutions of global governance (on the privileging of Western expertise, see Kunz, 2016). The nature of this relationship sits in continuity with the observation that feminist work is often done from locations that are neither fully inside nor fully outside an academic discipline, professional organisation, or social formation (Collins, 1986, HesseBiber, 2012, Whitmore, 2014). Accordingly, feminist theorists have challenged the fixity of the insider/outsider divide, noting that it "sets up a false separation that neglects the interactive processes through which 'insiderness' and 'outsiderness' are constructed" (Naples, 1996). Rather than attempt to fix such an unstable binary, I argue that these interactive processes are captured by the concept of positional slippage.

The process of positional slippages from researcher to friend, and from researched to researcher, has been documented in the literature on gender expertise. Megan Bastick and Claire Duncanson speak of the researcher/researched relationship turning into friendship, describing "feelings of warmth and respect for individuals within the military that we come to know" in their interrogation of what being a "critical friend" to these individuals entails (2015). Proximity can also lead to crossings over the 
boundary between academic and practitioner. Sometimes the blurring of this boundary takes the form of empathetic identification and cooperation, as identified by Elisabeth Prügl, who describes her work researching gender experts as written from the standpoint of, following Christine Sylvester, an "empathetic co-operator" (2016). Empathetic cooperation is "a process of positional slippage" that results from paying close and serious attention to the concerns and viewpoints of others (Sylvester, 1994). In other instances, the practice of gender expertise altogether defies attempts to establish boundaries between academics and practitioners. Individuals partaking in this epistemic community are regularly involved both in developing the practice of gender expertise, and generating knowledge about this practice through academic publishing (see for example, Myrttinen and Swaine, 2015, Mackay, 2005, Harcourt, 2017, Stern and Zalewski, 2009).

Third, moments of political solidarity contributed to fostering proximity with some of the research participants. While I name my political commitments as 'feminist', research on gender expertise has noted that gender experts have complex and diverging relationships to feminism (Kunz et al., 2017). Indeed, several of the gender experts I interviewed - especially male military officers - actively disavowed feminism and sought to distance themselves from it. At the same time, other participants detailed how their work was motivated by feminist investments. As Malcolm*, a gender expert in a Western European INGO put it: "I feel like I'm first a feminist and second a practitioner... [My practice] has the goal of contributing to social transformation through the empowerment of women" (e-mail exchange, 10 May 2016). In agreement with Malcolm's declaration, many gender experts I spoke with made reference to "common goals" shared by academics and practitioners, referring to broad ideas about gender equality and transformative peace and security practices. Proximity flowed from this notion of common purpose. Which is not necessarily to say that this common purpose was always clearly articulated and agreed upon - indeed, and as is often the case, "feminism was not a uniform referent even for those of us who regularly deployed it to name the politics of our intellectual investments" (Wiegman, 2016, emphasis in original). Solidarity does not, then, signal complete agreement, but rather alliance.

In sum, this research on gender training involved a heterogeneous group of gender experts, which led to research relationships characterised by different levels of proximity. This proximity stems from ongoing relationships, positional slippages, and feminist political solidarity. Some of these factors are relatively stable - such as ongoing relationships - whereas others are more fluid and contingent such as moments of political solidarity. What, then, does it mean to produce knowledge from relations of proximity? What tensions and opportunities arise from these entanglements? What are the responsibilities of the researcher? I situate these questions within feminist theorising of epistemology and methodology, as explored in the next section.

\section{FEMINIST METHODOLOGY AND CRITICAL FRIENDSHIP}

This case study sits in continuity with an extensive body of feminist literature on methodology, committed to examining the multi-faceted ways in which feminist scholars have tackled intertwined questions of epistemology, methodology, and method in keeping with a "feminist research ethic" (Ackerly and True, 2008, for an excellent review of this literature, see also Hesse-Biber, 2012). It is well established in this literature that though feminist research shares a commitment to feminist struggle, there is no singular feminist methodology, and work in this field encompasses a variety of 
political and epistemic commitments (Harding and Norberg, 2005, Hesse-Biber, 2012). Broadly, the research this article draws from is empathetic to critical feminist scholarship and intersectional analytical sensibilities (Cho et al., 2013, Wibben, 2016). However, for the purposes of this article, I am less interested in (re-)drawing lines of demarcation between different types of feminist approaches, than I am in gathering insights from a range of interventions that have addressed the researcher/researched relationship. In this section, I first situate my analysis in broader feminist epistemological and methodological debates around the researcher/researched relationship, and then discuss the concept of 'critical friendship' as a guiding tool for navigating research in relations of proximity.

Feminist research methodologies commonly advocate for reflexivity regarding the locatedness of the researcher in relation to her research subject(s). While some mainstream approaches to social science advocate maintaining a distance from those researched in the interests of rational objectivity, feminist scholarship has by and large concluded that such aspirations to epistemic purity are besides being an undesirable exercise of masculinist epistemological authority - unattainable in the first place. In her influential 1988 intervention in the "objectivity debate," Donna Haraway argues for situated knowledges: "for politics and epistemologies of location, positioning, and situating, where partiality and not universality is the condition of being heard to make rational knowledge claims" (1988). Haraway rejects the notion that there is such a thing as innocent knowledge, arguing instead that all knowledge is situated within political, social, and interpersonal relationships. Proximity, in this epistemological tradition, is not an a priori problem for research that should or could be overcome. It is, however, a consideration that requires analytically reflexive attention. It requires having "simultaneously an account of radical historical contingency for all knowledge claims, a critical practice for recognizing our own 'semiotic technologies' for making meanings, and a no-nonsense commitment to faithful accounts of a 'real' world" (Haraway, 1988, see also Harding, 1993, Code, 2014, Wolf, 1996). These insights have come to characterise feminist research, often articulated as a commitment to writing in the positionality of the researcher and engaging in analytical reflexivity (Fonow and Cook, 1991, Ackerly et al., 2006). Such 'writing in' of the researcher typically involves writing in the first person, as well as engaging explicitly with the social situatedness of the researcher, not with a view to "'navel-gazing', but as the basis for transformative politics" (Henry et al., 2009, see also Enloe, 2016).

This concern for reflecting on researcher positionality is intimately linked with continued attentiveness to the operations of power in feminist research (Hesse-Biber, 2012, Ackerly and True, 2008, Fonow and Cook, 1991). While the concern with power in the researcher endeavour sought, at the outset, to make visible how the researcher exercises power over the research subject, recent feminist analyses have productively drawn attention to the multi-dimensional and shifting nature of operations of power (Henry et al., 2009, Thapar-Björkert and Henry, 2004). Further, feminist scholars have highlighted how some attempts to ameliorate unequal power relationships in research - for example by fostering partnership and friendship - may in fact pose a new set of ethical dilemmas (Preissle and Han, 2012, Kirsch, 2005, Huisman, 2008). For example, in the context of research with gender experts, the research relationship may become more exploitative because, given the enduring nature of the relationship, the researched may feel personally obliged to the researcher. Proximity to research participants does not, then, simply resolve the unequal power relationships of a more distant and hierarchical research relationship, rather, "[d]istance and intimacy create their own problems" (Preissle and Han, 2012). Accordingly, some scholars caution that researchers should not 
confuse "friendliness" with "friendship", and should maintain clear boundaries with research participants (Kirsch, 2005). However, when the research occurs within the context of enduring relationships, such strategies are not always readily available.

Feminist scholars studying gender expertise have proposed instead that such research relationships should be informed by the principles of "critical friendship" (Chappell and Mackay, 2015, Bastick and Duncanson, 2015). Chappell and Mackay suggest that researchers who are critical friends are external to the organisation, and hold relevant expertise and (some) shared goals with those researched. Their acting as critical friends involves balancing support with critical analysis, challenging assumptions, speaking hard truths constructively, and making contextual judgments. Overall, this relationship involves balancing the contradictions of an engaged and critical position (Chappell and Mackay, 2015). In this formulation, Chappell and Mackay draw on a concept developed in educational research, which describes a critical friend as someone who "is a trusted person who asks provocative questions, provides data to be examined through another lens, and offers critique of a person's work as a friend" (Costa and Kallick, 1993). Two aspects of this thinking about the research relationship as critical friendship are of particular interest for my purposes.

First, both the roles performed by 'critical friends' and the lineage of the concept from education studies suggest that using the concept to describe feminist research can be seen as one of a series of moves by which academic feminism "has constituted itself as feminism's mentor" (Wiegman, 2016). Positioning feminist academics as the mentors of gender experts certainly carries implications of hierarchy, but the question remains whether gender experts are also critical friends to the academics who research them. Notably, definitions of critical friends insist on a "commitment to understanding contingency" (Chappell and Mackay, 2015) and to "understand the context of the work presented" (Costa and Kallick, 1993). Following these commitments, I suggest there is potential for those studied to also be critical friends to researchers, through holding them accountable for providing contextually grounded and detailed accounts of their work.

Second, the original conceptualisation of critical friendship formulated by Costa and Kallick posits: "The friend is an advocate for the success of that work" (1993). Chappell and Mackay moderate this statement by noting that critical friendships are characterised by "(some) shared goals" (2015). This parenthetical addition of "(some)" is significant, as it flags concerns about the political investments of research. Feminist scholars have long insisted not only that there is no 'innocent knowledge' and that all research is political, but that feminist research should be useful to feminist politics (hooks, 1994, Lorde, 2007, Ferguson, 2017). But when it comes to research on gender expertise, if feminist research should be useful to feminist politics, then whose feminist politics should researchers align themselves with? Feminist researchers are divided on the transformative potential of practices such as gender training and gender mainstreaming (Sexwale, 1996, Bustelo et al., 2016a, Squires, 2005). The concern over the co-optation of feminist politics has been especially pronounced in the field of international peace and security, where feminist researchers have been particularly circumspect about allying themselves with military institutions implicated in martial violence and imperial incursions (Enloe, 2000, Reeves, 2012, Whitworth, 2004, Kronsell, 2012, Pratt, 2013, Bastick and Duncanson, 2015). In the context of this ambiguity, the question becomes, can the practice of gender expertise be assumed to serve the interests of the 'beneficiaries' of its interventions? If not, is it defensible to support gender experts even when their work may be counter-productive to the well-being of those their interventions target (or do not target)? The insistence that critical friends support the goals of gender 
experts appears to leave little space for feminist ambiguity about the politics of gender expertise. In this context, the parenthetical qualification that researchers may share some - but not all - goals of the gender experts they research provides much-needed conceptual latitude.

Few works in this body of literature claim to provide a neat resolution for the methodological, political, and ethical dilemmas that feminist research poses. However, the intractability of such dilemmas calls for more rather than less attention to them in the research process. The lack of ultimate resolution underscores the pertinence of continued reflection on how to navigate the research process in a way that is (more) methodologically rigorous, ethically sound, and politically responsible. In the following section, I outline two key ways in which relations of proximity played out in my research, and their implications for knowledge production.

\section{THE POTENTIAL AND PROBLEMS OF PROXIMITY \\ Critical friendship works both ways}

Critical friendship is a paradoxical concept, which requires balancing contradictory performances of support and critique (Chappell and Mackay, 2015). It requires balancing an "ethic of caring" (Collins, 1989) towards research participants with political commitments to those on whose behalf gender expertise is practiced (Gray, 2016). At the same time, critical friendship requires another kind of balancing act: it requires that researchers also create space for those they research to be critical friends to the researcher. In this section, I begin with the latter question of critical friendship working in both ways, suggesting a commitment to dialogue as a way of navigating them (Prügl, 2016). I then turn to the question of balancing the demands of such friendship with political commitments.

The supportive aspect of critical friendship is evident in how many gender experts describe alliances with feminist academics as a coping strategy. Gender experts often work in institutions where they are relatively isolated, pushing a change agenda against resistance. As Malcolm*, a gender expert in a Western European INGO, explained: "we often work in environments where we are misunderstood and hence academia becomes a safe space to express ourselves and a place where we get vindication for our work in terms that reflect our feminist values" (email exchange, 8 May 2016). Similarly, Nadine Puechguirbal describes "being a feminist observer" and "building alliances" as strategies for coping as a gender advisor in the highly masculine and militarised world of UN peacekeeping (2017). This type of support speaks to one way in which researchers support gender experts, to the potential "therapeutic value" of participating in research (Fonow and Cook, 1991).

However, creating the type of safe space Malcolm referred to requires emotion work (Mirchandani, 2003). Safe space is not a pre-given effect of proximity but requires careful attention, as the relationship of proximity can also be emotionally hurtful. Sarah*, a gender expert in a Western European INGO, described her frustration at "feeling like you're endlessly banging your head against the wall trying to make things better and then [academics] who fundamentally want the same things you do come along and tell you you're part of the problem" (email exchange, 6 May 2016). Many gender experts I spoke with shared Sarah's assessment, and described feeling "judged", "criticised", and "attacked" by their academic counterparts. These descriptions of hurt and frustration point to the need to exercise attentiveness to the role of emotion in relations of proximity: the personal relationships between the researcher and the gender expert can serve as a way of being supportive, 
but they can also be hurtful to those being researched. This leaves the researcher with an open question that necessitates on-going, situational judgments: when is such frustration productive? When is it indispensable for our political goals? When it is destructive or harmful?

A dialogic research process is indispensable to navigating these questions (Prügl, 2016). The gender experts I spoke with voiced frustration not necessarily at having their practice subjected to critique, but for the basis on which such critique was formulated. They felt that critical accounts did not reflect the understanding of contingency and contextual judgements that Chappell and Mackay outline as a key feature of critical friendship (2015). Johanna*, a gender expert in a Western European INGO, described attending an academic workshop where she felt she was "being attacked for being a practitioner because of, you know, promoting liberal peace". She had tried to expose nuances in different approaches among practitioners, but her analysis was discredited:

It's like: 'You know these things, but I've done research'. As a practitioner, I think I have a lot of access to these kind of different experiences and reflections on practice of different organisations that are just not captured at the moment in academia (Interview, 4 September 2016).

Johanna's experience appears symptomatic of her analysis being attributed to experience rather than to knowledge - she was not seen as having conducted the kind of research that would allow her to make knowledge claims. Johanna's complaint can be read as seeking to hold feminist academics to account for not taking her experiences seriously - for not upholding the commitment of feminist research to taking women's experiences seriously (Code, 2014, Scott, 1992). Critical friendship, in this case, encourages the researcher to provide accounts that are accurately contextualised.

Opening up the space for gender experts to talk back to research means that the research will be held accountable not only for its contextual accuracy but also for its utility. Sarah* articulated the problem as that which "does piss off practitioners a lot is when academics are endlessly critical of the aid industry, and totally rightly so, but then don't offer anything constructive about doing better". Her frustration nonetheless speaks to an expectation that academics could or should produce useful work - in contrast to not-uncommon perceptions of academic work as basically useless to the world of practice (Bustelo et al., 2016b). In other words, these gender experts hold academic work accountable to another one of its self-proclaimed political investments: that of research being useful to feminist politics. Their decision to be both engaged and critical in relation to academic work suggests that they are being critical friends to academics in return - mentorship and friendship are not a one-way street.

It is at this juncture that the question of who our research should be accountable to reveals the tension inherent in the political commitment of producing useful research. The dangers implied in the quest to produce research that is useful to gender experts was demonstrated in an exchange with Anna*, a gender expert in a North American military, who claimed: "we need more data ... like the statistics that show that women's involvement in peace agreements leads to more sustainable peace, or the US Ranger teams that had cultural support teams had $20 \%$ more targets". She followed up this latter example, her voice not devoid of irony: "It showed that it's more mission effective. They can kill more people" (Interview, 7 June 2017). In her example, US military teams that included women were able to gather more information from the local population in an area of military operations; information that allowed the teams to identify more "enemies", or targets to be killed. This demand 
made of feminist research exposes the ways in which supporting the goals of (military) gender experts can become implicated in the exercise of martial violence, and cause harms to 'other' women. It underscores the importance of recognising that critical friendship involves some shared goals between academics and gender experts (Chappell and Mackay, 2015). Which is not to say that opposing goals are necessarily fixed and non-negotiable. Many gender experts themselves engage in critical reflections of their work. Puechguirbal, for example, shares her own ambiguities, asking: "Are we deceiving ourselves in pretending that we can challenge the system from within? What is the price to pay?" (2017). Accordingly, not only may support in the context of critical friendship be selective depending on the goals at stake, these goals themselves should be subject to dialogue and negotiation in a bidirectional understanding of critical friendship.

The process of negotiating such goals reminds us that the ethical responsibilities of the researcher do not stop with the research participants, but also relate to those affected by the work of gender expertise (Gray, 2016). While critical friendship allows researchers to be held accountable for providing well-grounded accounts of the realities of gender experts, it is imperative to note that such accounts simultaneously produce another set of silences. I turn to this question in the next and final section.

\section{Proximity and the politics of representation}

The ethical and political dilemmas of critical friendship pertain not only to what happens within the relationship, but also to the silences this dynamic produces. Accounting for the social location of the researcher as a critical friend to gender experts requires asking methodological and political questions about where knowledge is produced from and whose voices it centres (Mohanty, 2003). Proximity to gender experts shaped in important ways what I was able to hear and understand during my research (Harding, 1993, Henry, 2003). In this section, I provide an account of how proximity worked in this context in ways that privilege the perspectives of gender experts located primarily in the Global North, and consider ways of ameliorating problematic re-productions of global knowledge structures.

In my participant observation of training courses, relationships of critical friendship were accentuated, because I was associated with the trainers. The course leaders were usually the gatekeepers who granted me access to their training. Sometimes this access was based on a formal reciprocal arrangement, which involved my support in delivering the training. At other times, such support was informal, as some of the trainers would take advantage of the presence of a gender studies researcher on their course to seek my advice on the content of the training. While my association with the training team had the potential to concern trainees about my positional power, in practice, I concluded that I was being read as mostly harmless. The training participants seemed keenly aware that I did not exercise institutional power in the hierarchical structure of military and police organisations. Rather, they tended to negotiate my ambiguous status as an institutional outsider through humour, dubbing me the "pet civilian", or "course mascot".

However, these light-hearted exchanges did not overcome the effects of my proximity to the course facilitators. During participant observation of training courses, I was interested both in how training is practiced by gender experts, as well how gender knowledge is interpreted, contested, and renegotiated by training audiences. I was interested in hearing different points of view and reflections on how training was experienced. Especially in the course that I observed in West Africa, I was interested in interrogating the fact that the course involved a majority white European facilitation 
team, who taught an audience of exclusively West African police officers. However, my attempts to discuss this dynamic were largely unsuccessful, demonstrating the ways in which this encounter was racialized. In my conversations with the West African training participants, if they felt frustration or indignation with the fact that the European facilitators tended to speak from a Eurocentric perspective, often betraying a complete lack of understanding of the context these police officers were working in, they did not volunteer to share these feelings with me. My questions about this dynamic to training participants were met with "[c]ourtesy and form, traditional dignity, [and] respectful dismissal" (Angelou, 1986). After broaching the subject a few times to encounter polite dismissal, I decided not to push the matter further. I interpreted their decision not to unpack the colonial power dynamic of the training with me as that of "an agent of withholding' ... who refuses to yield an authentic native voice" (Spivak cited in Dhawan, 2012, see also Simpson, 2007). My research process - spending a week or two with trainers and participants, did not enable the development of the kinds of relationships of trust and cross-cultural communication that would have allowed us to overcome such reservations. I had to recognise that despite my desire to formulate a post-colonial critique of some of the training practices on the course, the training participants associated me with the European trainers. I often pass as white, and my institutional positioning in London and fluency in Western cultural scripts meant that I came to these encounters equipped with the "colonizer's language/tools/knowledge" (Thapar-Björkert and Henry, 2004). This association with the colonizer circumscribed what trainees would say in front of me and undoubtedly also what I was able to understand. In sum, my proximity with gender experts - the same proximity that lends itself to the practice of critical friendship - led to the representational privileging of their voices in ways which "act to exclude and marginalize ways of being and doing that do not conform to the knowledge transfer scenario" (Kunz, 2016).

My positionality as a researcher is not, therefore, one from which I can claim to represent the perspectives and interests of those who are marginalised in the knowledge production processes of gender training. What I have attempted to do to address this problem, instead, is to interrogate how these mechanisms of exclusion operate from the inside. In this undertaking, I am indebted to the post-colonial project identified by Dipesh Chakrabarty to provincialise Euro-centric narratives (2008), and the Black feminist critique that calls for white feminist researchers to, as Hazel V. Carby put it, "try to uncover the gender-specific mechanisms of racism among white women" (1982). What this entails for analytical practice is sustained attention to how knowledge is produced: what types of knowledge are seen as valid, who gets to participate in the design of curricula, and which voices are regarded as authoritative. Attention to these mechanisms carries the potential to reveal the hierarchical operations of power involved in the production and circulation of knowledge. Identifying such exclusionary operations goes some way toward provinicialising the resulting knowledge, by portraying it as partial and contextualising the ways in which it emerges from specific power dynamics. It further enables the identification of ways in which Western feminist projects of gender training derive their power from, and collude with a neo-colonial order that empowers Western women to speak for women in the Global South (Pratt, 2013). In other words, I contend that while positionality inevitably produces partial accounts of the topic of research, a range of political and analytical positions are available in every location. The limitations of positionality should not just serve as caveat for whose voices are prioritised, but they should provide impetus to critically interrogate the workings of power from the locations that are available to the researcher, coupled with efforts to learn from and cede space to knowledges produced in the Global South (Medie and Kang, 2018). 


\section{CONCLUSION}

This article has described ways in which research on gender experts and gender expertise is often conducted out of relations of proximity, and interrogated how proximity inflects the politics of research. Grounded in a case study of research with gender experts involved in gender training for uniformed peacekeepers, and drawing insights from feminist methodology and broader research on gender expertise, this article has interrogated the implications of the suggestion that such research relationships should take the principles of 'critical friendship' as its guide. I further develop the concept of 'critical friendship' to suggest that such friendship should be a dialogic relationship that also creates space for those researched to mentor the researcher. I insist that there must be space in feminist research and politics for ambiguity, and as such, the supportive nature of such friendship does not entail a blanket acceptance of all goals as shared. Finally, I offer a reminder that the ethical responsibilities of the researcher are not contained within the relationship of critical friendship. Attention to positionality, and recognition that the research deals with a field that is dominated by the knowledge and ways of being and acting of the Global North, reveals the ways in which such relations of proximity facilitate the representational privileging of those same actors.

Beyond the realm of methodology, this interrogation of critical friendships further complicates the notion of gender expertise as a contested field: it makes visible the ways in which the researcher partakes in this contestation. The roles that the researcher play are numerous - ranging from formally participating in the development of gender expertise as, for example, consultant or trainer, to the more subtle forms of alliance that take the form of emotional work, informal advice, collaborative strategising, or critical friendship. When proximity flows from shared political goals, the feminist researcher is differentially placed vis-à-vis different gender experts. She is implicated in the dynamics of contestation and shaping political strategies for this work. This, I argue, suggests a responsibility on the part of the researcher to engage in constant critical interrogation of her relation to the field in which her research intervenes. In the specific case of gender expertise in the field of peace and security, it highlights the continued urgency of interrogating the relationship between feminism and militarism. 


\section{Funding details}

This work was supported by the LSE Centre for Women, Peace and Security through a fieldwork grant.

\section{Conflicts of interest}

The Author declares that there is no conflict of interest.

\section{Acknowledgments}

I would like to thank the following individuals for their thoughtful engagement with this manuscript in various stages of its development: Rahel Kunz, Elisabeth Prügl, Sevan Beukian, Ania Plomien, Marsha Henry, the editors of the European Journal of Politics and Gender, and three anonymous reviewers.

\section{Author biography}

Aiko Holvikivi is a PhD Candidate in Gender Studies and an affiliated researcher at the Centre for Women, Peace and Security at LSE. Her work focuses on transnational movements of people and of knowledges, and how they are produced by and productive of gender and (in)security.

\footnotetext{
Notes

* In order to protect the anonymity of my research participants, I use pseudonyms to refer to individuals, and do not identify specific countries or organisations.

${ }^{1}$ Peacekeeping missions comprise of civilian staff, police personnel, and military contingents. 'Uniformed peacekeeping personnel' in this context serves as shorthand for police and military peacekeepers.
} 


\section{REFERENCES}

ACKERLY, B. \& TRUE, J. 2008. Reflexivity in Practice: Power and Ethics in Feminist Research on International Relations. International Studies Review, 10, 693-707.

ACKERLY, B. A., STERN, M. \& TRUE, J. 2006. Feminist Methodologies for International Relations. In: ACKERLY, B. A., STERN, M. \& TRUE, J. (eds.) Feminist Methodologies for International Relations. Cambridge: Cambridge University Press.

ANGELOU, M. 1986. All God's Children Need Travelling Shoes, London, Hachette Digital.

BASTICK, M. \& DUNCANSON, C. 2015. Engaging with Militaries: Strategies, Sanctions and Implications. European Consortium for Political Research 4th European Conference on Politics and Gender. University of Uppsala, Sweden.

BUSTELO, M., FERGUSON, L. \& FOREST, M. 2016a. Conclusions. In: BUSTELO, M., FERGUSON, L. \& FOREST, M. (eds.) The Politics of Feminist Knowledge Transfer: Gender Training and Gender Expertise. UK: Palgrave Macmillan.

BUSTELO, M., FERGUSON, L. \& FOREST, M. 2016b. Introduction. In: BUSTELO, M., FERGUSON, L. \& FOREST, M. (eds.) The Politics of Feminist Knowledge Transfer: Gender Training and Gender Expertise. UK: Palgrave Macmillan.

CARBY, H. V. 1982. White Woman Listen! Black Feminism and the Boundaries of Sisterhood. In: CENTRE FOR CONTEMPORARY CULTURAL STUDIES (ed.) The Empire Strikes Back: Race and Racism in 70s Britain. London: Hutchinson.

CHAKRABARTY, D. 2008. Provincialising Europe: Postcolonial Thought and Historical Difference, New Jersey, Princeton University Press.

CHAPPELL, L. \& MACKAY, F. 2015. Critical Friends and De(con)structive Critics: Dilemmas of Feminist Engagement with Global Governance and Gender Reform Agendas. European Consortium for Political Research 4th European Conference on Politics and Gender. Uppsala, Sweden.

CHO, S., CRENSHAW, K. W. \& MCCALL, L. 2013. Toward a Field of Intersectionality Studies: Theory, Applications, and Praxis. Signs, 38, 785-810.

CODE, L. 2014. Feminist Epistemology and the Politics of Knowledge: Questions of Marginality. In: EVANS, M., HEMMINGS, C., HENRY, M., JOHNSTONE, H., MADHOK, S., PLOMIEN, A. \& WEARING, S. (eds.) The SAGE Handbook of Feminist Theory. London: SAGE.

COLLINS, P. H. 1986. Learning from the Outsider Within: The Sociological Significance of Black Feminist Thought. Social Problems, 33, S14-S32.

COLLINS, P. H. 1989. The Social Construction of Black Feminist Thought. Signs, 14, 745-773.

COSTA, A. \& KALLICK, B. 1993. Through the Lens of a Critical Friend. Educational Leadership, 51, 4951.

DHAWAN, N. 2012. Hegemonic Listening and Subversive Silences: Ethical-political Imperatives. In: LAGAAY, A. \& LORBER, M. (eds.) Destruction in the Performative. Amsterdam: Rodopi.

ENLOE, C. 2000. Maneuvers: The International Politics of Militarizing Women's Lives, Berkeley, University of California press.

ENLOE, C. 2016. Afterword: Being Reflexively Feminist Shouldn't be Easy. In: WIBBEN, A. T. R. (ed.) Researching War: Feminist Methods, Ethics and Politics. New York: Routledge.

EYBEN, R. 2010. Subversively Accommodating: Feminist Bureaucrats and Gender Mainstreaming. IDS Bulletin, 41, 54-61.

FERGUSON, K. E. 2017. Feminist Theory Today. Annual Review of Political Science, 20, 269-286.

FONOW, M. M. \& COOK, J. A. 1991. Back to the Future: A Look at the Second Wave of Feminist Epistemology and Methodology. In: FONOW, M. M. \& COOK, J. A. (eds.) Beyond Methodology: Feminist Scholarship as Lived Research. Indianapolis: Indiana University Press.

GRAY, H. 2016. Researching from the Spaces in Between? The Politics of Accountability in Studying the British Military. Critical Military Studies, 2, 70-83.

HARAWAY, D. 1988. Situated Knowledges: The Science Question in Feminism and the Privilege of Partial Perspective. Feminist Studies, 14, 575-599. 
HARCOURT, W. 2017. Feminist Co-optation and Body Politics in Development. In: VERSCHUUR, C. (ed.) Expertes en Genre et Connaissances Féministes sur le Développement : Qui Sait ? Paris: L'Harmattan.

HARDING, S. 1993. Rethinking Standpoint Epistemology: What is "Strong Objectivity"? In: ALCOFF, L. \& POTTER, E. (eds.) Feminist Epistemologies. London: Routledge.

HARDING, S. \& NORBERG, K. 2005. New Feminist Approaches to Social Science Methodologies: An Introduction. Signs, 30, 2009-2015.

HENRY, M. 2003. Where Are You Really From? Representation, Identity and Power in the Fieldwork Experiences of a South Asian Diasporic. Qualitative Research, 3, 229-242.

HENRY, M., HIGATE, P. \& SANGHERA, G. 2009. Positionality and Power: The Politics of Peacekeeping Research. International Peacekeeping, 16, 467-482.

HESSE-BIBER, S. N. 2012. Feminist Research: Exploring, Interrogating, and Transforming the Interconnections of Epistemology, Methodology, and Method. In: HESSE-BIBER, S. N. (ed.) Handbook of Feminist Research: Theory and Praxis. Second ed. California: SAGE Publications.

HOOKS, B. 1994. Teaching to Transgress: Education as the Practice of Freedom, New York, Routledge.

HUISMAN, K. 2008. "Does This Mean You're Not Going to Come Visit Me Anymore?": An Inquiry into an Ethics of Reciprocity and Positionality in Feminist Ethnographic Research. Sociological Inquiry, 78, 372-396.

KIRSCH, GESA E. 2005. Friendship, Friendliness, and Feminist Fieldwork. Signs, 30, 2163-2172.

KRONSELL, A. 2006. Methods for Studying Silences: Gender Analysis in Institutions of Hegemonic Masculinity. In: ACKERLY, B. A., STERN, M. \& TRUE, J. (eds.) Feminist Methodologies for International Relations. Kindle edition ed. Cambridge: Cambridge University Press.

KRONSELL, A. 2012. Gender, Sex, and the Postnational Defense: Militarism and Peacekeeping New York, Oxford University Press.

KUNZ, R. 2016. Windows of Opportunity, Trojan Horses, and Waves of Women on the Move: DeColonizing the Circulation of Feminist Knowledges through Metaphors? In: BUSTELO, M., FERGUSON, L. \& FOREST, M. (eds.) The Politics of Feminist Knowledge Transfer: Gender Training and Gender Expertise. UK: Palgrave Macmillan.

KUNZ, R., PRÜGL, E. \& THOMPSON, H. 2017. Gender Expertise in International Governance: A Contested Field. European Conference on Politics and Gender. Lausanne.

LORDE, A. 2007. The Master's Tools Will Never Dismantle the Master's House. In: LORDE, A. (ed.) Sister Outsider. New York: Crossing Press.

MACKAY, A. 2005. Mainstreaming Gender in United Nations Peacekeeping Training: Examples from East Timor, Ethiopia, and Eritrea. In: MAZURANA, D. E., RAVEN-ROBERTS, A. \& PARPART, J. L. (eds.) Gender, Conflict and Peacekeeping. Oxford: Rowman and Littlefield.

MEDIE, P. A. \& KANG, A. J. 2018. Power, Knowledge and the Politics of Gender in the Global South. European Journal of Politics and Gender, 1, 37-54.

MIRCHANDANI, K. 2003. Challenging Racial Silences in Studies of Emotion Work: Contributions from Anti-Racist Feminist Theory. Organization Studies, 24, 721-742.

MOHANTY, C. T. 2003. Feminism without Borders: Decolonizing Theory, Practicing Solidarity, Durham \& London, Duke University Press.

MYRTTINEN, H. \& SWAINE, A. 2015. Monster Myths, Selfies and Grand Declarations. International Feminist Journal of Politics, 17, 496-502.

NAPLES, N. A. 1996. A Feminist Revisiting of the Insider/Outsider Debate: The "Outsider Phenomenon" in Rural lowa. Qualitative Sociology, 19, 83-106.

PRATT, N. 2013. Reconceptualising Gender, Reinscribing Racial-Sexual Boundaries in International Security: The Case of UN Security Council Resolution 1325 on 'Women, Peace and Security'. International Studies Quarterly, 57, 772-783.

PREISSLE, J. \& HAN, Y. 2012. Feminist Research Ethics. In: HESSE-BIBER, S. N. (ed.) Handbook of Feminist Research: Theory and Praxis. Second ed. California: SAGE Publications. 
PRÜGL, E. 2016. How to Wield Feminist Power. In: BUSTELO, M., FERGUSON, L. \& FOREST, M. (eds.) The Politics of Feminist Knowledge Transfer: Gender Training and Gender Expertise. UK: Palgrave Macmillan.

PRÜGL, E. \& THOMPSON, H. 2017. Gender Experts in International Governance: Mapping the Contours of a Field. In: VERSCHUUR, C. (ed.) Expertes en Genre et Connaissances Féministes sur le Développement: Qui Sait ? Paris: L'Harmattan.

PUECHGUIRBAL, N. 2017. 'I speak fluent partriarchy, but it's not my mother tongue' Perspectives of a Feminist Insider within International Institutions. In: VERSCHUUR, C. (ed.) Expertes en Genre et Connaissances Féministes sur le Développement : Qui Sait ? Paris: L'Harmattan.

REEVES, A. 2012. Feminist Knowledge and Emerging Governmentality in UN Peacekeeping. International Feminist Journal of Politics, 14, 348-369.

SCOTT, J. W. 1992. Experience. In: BUTLER, J. \& SCOTT, J. W. (eds.) Feminists Theorize the Political London \& New York: Routledge.

SEDGWICK, E. K. 2008. Epistemology of the Closet, Berkeley, University of California Press.

SEXWALE, B. M. M. 1996. What Happened to Feminist Politics in 'Gender Training'? In: MAYNARD, M. \& PURVIS, J. (eds.) New Frontiers in Women's Studies: Knowledge, Identity, and Nationalism. London and Bristol, PA: Taylor \& Francis.

SIMPSON, A. 2007. On Ethnographic Refusal: Indigeneity, "Voice," and Colonial Citizenship. Junctures, $9,67-80$.

SQUIRES, J. 2005. Is Mainstreaming Transformative? Theorizing Mainstreaming in the Context of Diversity and Deliberation. Social Politics: International Studies in Gender, State \& Society, 12, 366-388.

STERN, M. \& ZALEWSKI, M. 2009. Feminist Fatigue(s): Reflections on Feminism and Familiar Fables of Militarisation. Review of International Studies, 35, 611-630.

SYLVESTER, C. 1994. Empathetic Cooperation: A Feminist Method For IR. Millennium, 23, 315-334.

THAPAR-BJÖRKERT, S. \& HENRY, M. 2004. Reassessing the Research Relationship: Location, Position and Power in Fieldwork Accounts. International Journal of Social Research Methodology, 7, 363-381.

WHITMORE, E. 2014. Researcher/Evaluator Roles and Social Justice. In: BRISOLARA, S., SEIGART, D. M. \& SENGUPTA, S. (eds.) Feminist Evaluation and Research: Theory and Practice. New York: The Guilford Press.

WHITWORTH, S. 2004. Men, Militarism \& UN Peacekeeping: A Gendered Analysis, London, Lynne Rienner.

WIBBEN, A. T. R. 2016. Introduction: Feminists Study War. In: WIBBEN, A. T. R. (ed.) Researching War: Feminist Methods, Ethics and Politics. New York: Routledge.

WIEGMAN, R. 2016. No Guarantee: Feminism's Academic Affect and Political Fantasy. Atlantis, 37, 13. WOLF, D. L. 1996. Situating Feminist Dilemmas in Fieldwork. In: WOLF, D. L. (ed.) Feminist Dilemmas in Fieldwork. Colorado: Westview Press. 